\title{
LETTERS
}

\section{Benefit of anti-TNF $\alpha$ treatment for nephrotic syndrome in a patient with juvenile inflammatory bowel disease associated spondyloarthropathy complicated with amyloidosis and glomerulonephritis}

\author{
P Verschueren, F Lensen, E Lerut, K Claes, R De Vos, B Van Damme, R Westhovens
}

Ann Rheum Dis 2003;62:368-369

$\mathrm{H}$ storically, AA amyloidosis accounts for almost half of the deaths among patients with juvenile chronic arthri-

tis, mainly due to complications of end stage renal failure. ${ }^{1}$ Improved survival has been reported in patients whose underlying inflammatory disorder was brought to remission. ${ }^{2}$ Tumour necrosis factor (TNF $\alpha$ ) blocking agents have been used successfully in the treatment of inflammatory disorders complicated with AA amyloidosis. ${ }^{3-5}$ We report the effect of TNF $\alpha$ in a case of AA amyloidosis secondary to juvenile spondyloarthropathy.

\section{CASE REPORT}

A 26 year old man with juvenile, inflammatory bowel disease associated spondyloarthropathy (HLA-B27+) was admitted to our hospital with proteinuria and ankle oedema.

He received combination therapy with methotrexate, sulfasalazine, methylprednisolone, and naproxen. His blood pressure was 130/80 mmHg. Table 1 shows the results of laboratory tests.

Ultrasound examination showed an increased bipolar size $(130 \mathrm{~mm})$ of both kidneys. A chest $x$ ray examination was normal. A renal biopsy showed deposition of amorphous eosinophilic material in several glomeruli, the interstitium, and the arterial walls. The diagnosis of amyloidosis was confirmed by positive Congo red and AA stains and by electron microscopy (non-branching fibrils, approximately $10 \mathrm{~nm}$ width). Focal extracapillary proliferative glomerulonephritis was also present. Immunofluorescence showed mild positivity for IgA in the amyloid deposits. A rectal biopsy confirmed the diagnosis and showed no active inflammatory bowel disease.

Treatment with sulfasalazine was discontinued, the dose of methylprednisolone increased (32 $\mathrm{mg} /$ day), and treatment
Table 1 Laboratory results at the time of admission

\begin{tabular}{|c|c|c|}
\hline & Result & $\begin{array}{l}\text { Normal } \\
\text { range }\end{array}$ \\
\hline Haemoglobin (g/l) & 73 & $130-180$ \\
\hline $\operatorname{ESR}(\mathrm{mm} / 1 \mathrm{st} h)$ & 82 & \\
\hline $\operatorname{CRP}(\mathrm{mg} / \mathrm{l})$ & 125 & $0.8-8$ \\
\hline Serum albumin $(g / l)$ & 16.9 & $37-53$ \\
\hline Creatinine clearance $(\mathrm{ml} / \mathrm{min})$ & 68.5 & $75.0-125.0$ \\
\hline C3 (g/l) & 0.77 & $0.50-0.90$ \\
\hline C4 (g/l) & 0.10 & $0.10-0.40$ \\
\hline $\mathrm{Clq} B A$ & Positive & \\
\hline Protein G BA & Positive & \\
\hline HAV & Negative & \\
\hline HBV & Negative & \\
\hline $\mathrm{HCV}$ & Negative & \\
\hline ANF & Negative & \\
\hline Rheumatoid factor & Negative & \\
\hline Serum protein electrophoresis & No paraproteins & \\
\hline Urinary protein excretion $(\mathrm{g} / 24 \mathrm{~h})$ & 8.78 & $0.00-0.15$ \\
\hline Urine sediment & $\begin{array}{l}\text { Dysmorphic } \\
\text { erythrocytes }\end{array}$ & \\
\hline & No haemoglobin casts & \\
\hline
\end{tabular}

ESR, erythrocyte sedimentation rate; $C R P, C$ reactive protein; $B A$ binding activity; $\mathrm{HAV}$, hepatitis $A$ virus; $\mathrm{HBV}$, hepatitis $B$ virus; $\mathrm{HCV}$, hepatitis $C$ virus; $A N F$, antinuclear factor.

with lisinopril started. Incomplete regression of proteinuria occurred after one month $(2.5 \mathrm{~g} / 24 \mathrm{~h})$.

Three months after diagnosis, treatment with anti-TNF $\alpha$ (Remicade, infliximab, Centocor, USA; $3 \mathrm{mg} / \mathrm{kg}$; weeks 0, 2, 6, 14 and every eight weeks following) was started because of persistent arthritis. At that time the dose of methylprednisolone was $16 \mathrm{mg} /$ day. With this treatment there was an
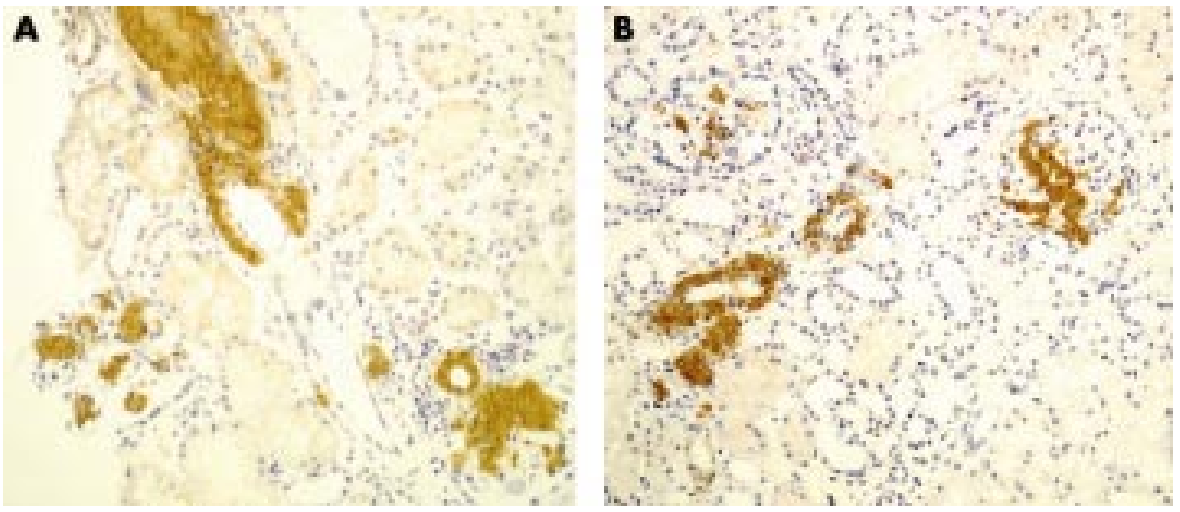

Figure 1 Renal biopsy specimen $(A)$ at baseline and $(B)$ after seven months of treatment. After seven months no decrease in the amount of amyloid is seen despite continuous infliximab treatment. AA stain, $\times 20$. 


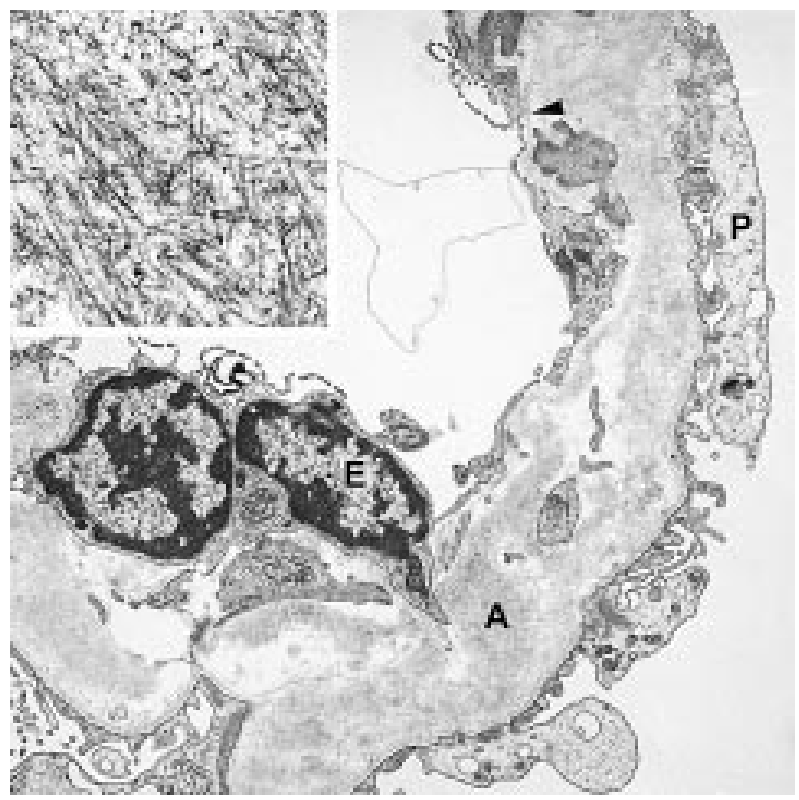

Figure 2 Amyloid depositions in glomeruli partly covered by newly formed glomerular basement membrane (x) 1 500). Inset: amyloid fibrils ( $x 72$ 500). Arrowhead indicates newly formed basement membrane. $E$, endothelium; $P$, podocytes; $A$, amyloid fibrils.

immediate clinical improvement (reduction of pain and disease activity on a visual analogue scale). After six months serum haemoglobin, $C$ reactive protein (CRP), albumin, and the erythrocyte sedimentation rate (ESR) returned to normal with further reduction of proteinuria. After nine months urine analysis was normal and protein excretion reduced to 0.24 $\mathrm{g} / 24 \mathrm{~h}$.

A renal biopsy was repeated after seven months of treatment. An equal amount of amyloid fibrils was present in the mesangium, the subendothelial, and subepithelial space. A newly formed basal membrane partly covered these deposits (figs 1 and 2). Immunofluorescence did not differ from the first biopsy, but there were no more signs of intra- or extracapillary proliferation.

\section{DISCUSSION}

Our patient presented with a nephrotic syndrome and dysmorphic haematuria. Renal biopsy showed amyloidosis and extracapillary proliferative glomerulonephritis. This association has been reported previously. ${ }^{6}$ Although it remains unclear whether there is a causal relationship between these renal conditions, crescent formation is a possible explanation for the rapid decline in renal function sometimes seen in amyloidosis.

In this case IgA staining was only mildly positive in the amyloid deposits and not in the glomerular mesangium, excluding IgA nephritis, known for its association with spondyloarthropathy.?

A possible explanation for the improvement of the proteinuria in our patient might be the direct effect of TNF $\alpha$ on the pathogenesis of the nephrotic syndrome. TNF $\alpha$ is known to play a part in glomerular inflammation ${ }^{8}$ and it can increase glomerular permeability for albumin. ${ }^{9}$ Both effects can be neutralised by anti-TNF $\alpha$ antibodies. The systemic administration of infliximab might well have resulted in an immediate suppression of local TNF $\alpha$ effects in the kidney, explaining the fast improvement of the proteinuria.

Another explanation might be the profound effect of TNF $\alpha$ blocking agents on the production of serum amyloid A protein. A reduction in the systemic amyloid load might result in decreased amyloid deposition and structural healing mechanisms at the level of amyloidotic organs. ${ }^{2}$ Like others we found no decrease of amyloid deposits. The new formation of glomerular basement membrane in our view is a secondary process not explaining decreased proteinuria, in contrast with reports by other authors. ${ }^{10}$ In amyloidosis, proteinuria results from defects in the slit membrane caused by continuous deposition of amyloid fibrils in the lamina rara externa. When amyloid deposition is discontinued, the precipitated amyloid becomes "encapsulated" in the basement membrane by new formation of the latter, preventing further damage to the slit membrane.

\section{Authors' affiliations}

P Verschueren, F Lensen, R Westhovens, Department of Rheumatology, University Hospitals Leuven, Herestraat 49, 3000 Leuven, Belgium

E Lerut, R De Vos, B Van Damme, Department of Morphology and Molecular Pathology, University Hospitals Leuven, Minderbroedersstraat 12, 3000 Leuven, Belgium

K Claes, Department of Nephrology, University Hospitals Leuven, Herestraat 49, 3000 Leuven, Belgium

$\mathrm{P}$ Verschueren and $\mathrm{F}$ Lensen contributed equally to this report.

Correspondence to: Dr P Verschueren;

patrick.verschueren@uz.kuleuven.ac.be

Accepted 30 November 2002

\section{REFERENCES}

1 David J, Vouyiouka O, Ansell BM, Hall A, Woo P. Amyloidosis in juvenile chronic arthritis: a morbidity and mortality study. Clin Exp Rheumatol 1993;1 1:85-90.

2 Gillmore JD, Lovat LB, Persey MR, Pepys MB, Hawkins PN. Amyloid load and clinical outcome in AA amyloidosis in relation to circulating concentration of serum amyloid A protein. Lancet 2001;358:24-9.

3 Drewe E, McDermott EM, Powell RJ. Treatment of the nephrotic syndrome with etanercept in patients with the tumor necrosis factor receptor-associated periodic syndrome. N Engl J Med 2000;343:1044-5

4 Ortiz-Santamaria V, Valls-Roc M, Sanmarti M, Holgado S, Lafont A, Olivé A, et al. Anti-TNF therapy in secondary amyloidosis [abstract]. Ann Rheum Dis 2002:61 (suppl I):abstr FRI0134.

5 Elkayam O, Hawkins PN, Lachmann H, Yaron M, Caspi D. Rapid and complete resolution of proteinuria due to renal amyloidosis in a patient with rheumatoid arthritis treated with infliximab. Arthritis Rheum 2002;46:2571-3.

6 Nagata M, Shimokama T, Harada A, Koyama A, Watanabe T. Glomerular crescents in renal amyloidosis: an epiphenomenon or distinct pathology? Pathol Int 2001;51:179-86.

7 Montenegro V, Monteiro RC. Elevation of serum IgA in spondyloarthropathies and $\lg \mathrm{A}$ nephropathy and its pathogenic role. Curr Opin Rheumatol 1999;1 1:265-72.

8 Pai R, Ha H, Kirschenbaum MA, Kamanna VS. Role of tumor necrosis factor-alpha on mesangial cell MCP-1 expression and monocyte migration: mechanisms mediated by signal transduction. J Am Soc Nephrol 1996:7:914-23.

9 McCarthy ET, Sharma R, Sharma M, Li JZ, Ge XL, Dileezpan KN, et al. TNF-alpha increases albumin permeability of isolated rat glomeruli through the generation of superoxide. J Am Soc Nephrol 1998;9:433-8.

10 Mandreoli M, Casanova S, Vianelli N, Pasquali S, Zucchelli P. Remission of nephrotic syndrome due to AA amyloidosis and initiation of glomerular repair after surgical resection of localized Castleman's sisease. Nephron 2002;90:336-40. 


\title{
A unique autoantibody pattern of positive anti-Jo-1, anti-UIRNP, and antiproteasome antibodies in autoimmune myositis as a diagnostic challenge
}

\author{
E Feist, M-L Schneider, M Brychcy, T Dörner, G-R Burmester, F Hiepe
}

Ann Rheum Dis 2003;62:370-371

T he presence of autoantibodies against tRNA synthetases is a specific serological feature of a clinically distinct entity of autoimmune myositis. This syndrome is characterised by an association of non-erosive arthritis, Raynaud's phenomenon, and alveolitis. The most common autoimmune response of this disease is directed against the histidyl-tRNA synthetase Jo- 1 and therefore also called the anti-Jo-l syndrome. ${ }^{1-3}$ In this report we describe a patient with a unique coincidence of anti-Jo-l antibodies with other myositis related autoantibodies directed to UIRNP typical for mixed connective tissue disease (MCTD) and proteasome.

\section{CASE REPORT}

In a 36 year old female patient, arthralgia, joint swelling, and fever led to the diagnosis of rheumatoid arthritis in 1998. Initial treatment comprised sulfasalazine and prednisolone. In February 2000, she was admitted to our department with a four month history of myalgia and weakness. Physical examination showed a tetraparesis affecting the proximal and peripheral muscles with an apparent areflexia. Gottron's sign was positive, while arthritis was not evident. A marked pathological spontaneous activity of all muscle groups was found on electrophysiological examination. Pulmonary function tests and thoracic $x$ ray results were normal.

Autoantibody analysis showed an antinuclear antibody titre of $1 / 2560$ with a pattern suspicious for a coincidence of anti-UIRNP- and anti-Jo-l antibodies (fig lA). Enzyme linked immunosorbent assay (ELISA) and immunoblotting confirmed the reactivity against RNP-A and B/B' as well as Jo-l (fig 1B). Moreover, antiproteasomal autoantibodies were detectable in ELISA, while other autoantibodies were negative. The antiproteasome antibodies were affinity purified by means of $20 \mathrm{~S}$ pro- teasome bound to BrCN-sepharose and subsequently tested in immunofluorescence (fig $\mathrm{IC}$ ). Circulating immune complexes were found to be raised and complement components $\mathrm{C} 3$ and C4 were decreased. Creatinine kinase (2579 U/l, normal 0-80), myoglobin (1942 $\mu \mathrm{g} / \mathrm{l}$, normal 0-70), lactate dehydrogenase, and transaminases were strongly enhanced. Other laboratory data were normal, including peripheral blood count, $\mathrm{C}$ reactive protein, renal and thyroid function tests. A muscle biopsy from the right quadriceps showed a strong perivascular and endomysial infiltration, predominantly by cytotoxic $\mathrm{T}$ lymphocytes $(\mathrm{CD} 8+)$ and B lymphocytes (CD20+).

The overall findings were consistent with a severe autoimmune myositis without any evidence of an infectious, malignant, or endocrine cause. The likelihood of sulfasalazine induced autoantibodies and disease was low, because the autoantibody response was specific and the disease continued after withdrawal of the drug. Therefore, treatment was started with steroids (initially $750 \mathrm{mg}$ methylprednisolone), leading to a rapid clinical improvement. Furthermore, monthly infusions of immunoglobulins (25 g over five days) were given. Because after a period of six months (prednisolone 12 $\mathrm{mg}$ /day) a flare recurred, another steroid bolus of $750 \mathrm{mg}$ methylprednisolone in combination with intravenous cyclophosphamide was given, leading to an improvement of all clinical symptoms. In the follow up, the course of the disease remains stable.

\section{DISCUSSION}

During the past decades, detection of autoantibodies has improved remarkably the diagnosis of connective tissue diseases and provided new insights into their pathogenesis. In
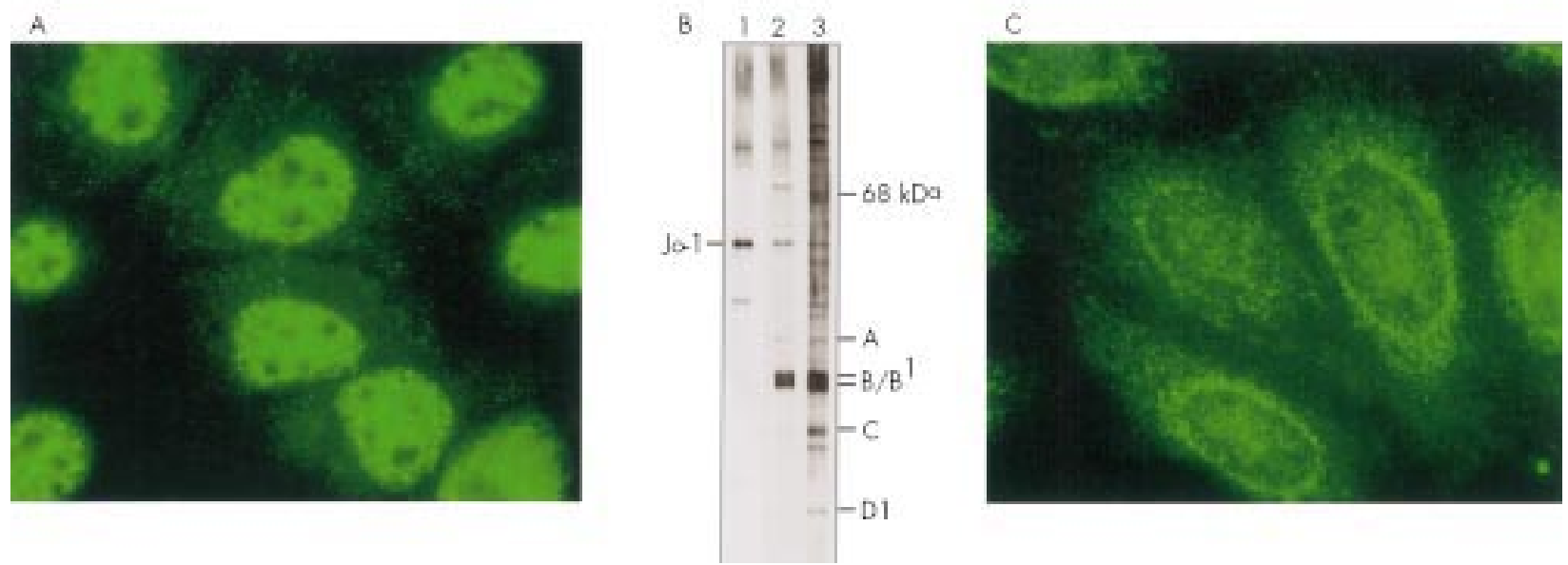

Figure 1 (A) Indirect immunofluorescence of the patient's serum showed a coarse granular nucleoplasmic pattern as well as fine speckled cytoplasmic staining in interphase HEp-2 cells. (B) Reactivity towards UIRNP antigens (A and B/B') and histidyl-tRNA synthetase (Jo-1) was confirmed by immunoblot (lane 2), which was performed as described previously using a MOLT-4 cell extract. ${ }^{9}$ Lanes 1 and 3 represent control sera recognising Jo-1 and Sm/U1RNP antigens, respectively. (C) Affinity purified antiproteasome antibodies showed a fine speckled cytoplasmic and nucleoplasmic staining on HEp-2 cells, which was not clearly distinguishable from the immunofluorescence pattern of anti-Jo-1 antibodies. 
this case, the simultaneous occurrence of anti-Jo-l and anti-UIRNP autoantibodies is a difficult diagnostic problem. Autoantibodies against Jo-l are usually highly specific for the anti-synthetase syndrome. ${ }^{1}$ However, in this case, the manifestation was incomplete, lacking pulmonary and peripheral vascular involvement. On the other hand, anti-UIRNP antibodies are a serological marker for MCTD, in which myositis is not an essential part but a typical symptom. ${ }^{2}$ However, the titre of the anti-UIRNP antibodies was not as high as it is typically for MCTD. The finding of low complement levels is not typical for myositis and might have been due to overlap of myositis with MCTD as complement factors can be decreased, especially in MCTD. Although an association between anti-Jo-l and anti-Ro/SSA $52 \mathrm{kDa}$ responses is relatively common, as reported by former studies, ${ }^{4-6}$ the coincidence of anti-Jo- 1 and anti-UIRNP antibodies appears to be less common. ${ }^{3}$ Autoantibodies against proteasome were recently found in association with autoimmune myositis and other connective tissue diseases. ${ }^{78}$ In this case, the unique autoantibody pattern detected impressively reflects the variability of these myositis related markers and emphasises that they belong to the common immune repertoire seen in autoimmune myositis.

\section{Authors' affiliations}

E Feist, M Brychcy, T Dörner, G-R Burmester, F Hiepe, Clinic for

Rheumatology and Clinical Immunology, University Hospital Charité, Humboldt University of Berlin, Schumannstr 20/ 21, D-10117 Berlin, Germany
M-L Schneider, Clinic for Gastroenterology, Hepatology and Endocrinology, University Hospital Charité

Correspondence to: DrE Feist; eugen.feist@charite.de

Accepted 8 August 2002

\section{REFERENCES}

1 Bernstein RM, Morgan SH, Chapman J, Bunn CC, Mathews MB Turner-Warwick $M$, et al. Anti-Jo-1 antibody: a marker for myositis with interstitial lung disease. BM 1984;289:151-2.

2 von Mühlen CA, Tan EM. Autoantibodies in the diagnosis of systemic rheumatic diseases. Semin Arthritis Rheum 1995;24:323-58.

3 Brouwer R, Hengstman GJ, Vree EW, Ehrfeld H, Bozic B, Ghirardello A, et al. Autoantibody profiles in the sera of European patients with myositis. Ann Rheum Dis 2001;60:116-23.

4 Frank MB, McCubbin V, Trieu E, Wu Y, Isenberg DA, Targoff IN. The association of anti-Ro52 autoantibodies with myositis and scleroderma autoantibodies. J Autoimmun 1999:12:137-42.

5 Rutjes SA, Vree Egberts WT, Jongen P, Van Den HF, Pruijn GJ, Van Venrooij WJ. Anti-Ro52 antibodies frequently co-occur with anti-Jo-1 antibodies in sera from patients with idiopathic inflammatory myopathy. Clin Exp Immunol 1997; 109:32-40.

6 Venables PJ. Antibodies to Jo-1 and Ro-52: why do they go together? Clin Exp Immunol 1997; 109:403-5.

7 Feist E, Dörner T, Kuckelkorn U, Schmidtke G, Micheel B, Hiepe F, et al. Proteasome alpha-type subunit $C 9$ is a primary target of autoantibodies in sera of patients with myositis and systemic lupus erythematosus. J Exp Med 1996;184:1313-18.

8 Feist E, Dörner T, Kuckelkorn U, Scheffler S, Burmester G, Kloetzel P. Diagnostic importance of anti-proteasome antibodies. Int Arch Allergy Immunol 2000; 123:92-7.

9 Riemekasten G, Marell J, Trebeljahr G, Klein R, Hausdorf G, Häupl T, et al. A novel epitope on the $C$-terminus of $\mathrm{SmDl}$ is recognized by the majority of sera from patients with systemic lupus erythematosus. J Clin Invest 1998; 102:754-63.

\section{Degenerative disc disease and pre-existing spinal pain}

\section{J Centeno, J Fleishman}

A pportioning pain and disability after a car accident or work related injury can be difficult. Many doctors who undertake this task often state that because an $x$ ray examination or magnetic resonance imaging (MRI) scan soon after the injury shows degenerative disc disease (DDD), some or all of the patient's spinal pain and disability must be pre-existing. This interpretation of imaging is not consistent with the peer reviewed medical published reports.

For this statement to be true, there would need to be a strong connection between MRI or $x$ ray evidence of DDD and pain/disability. If we look at this concept and compare it with the published reports, we see that DDD, as seen on imaging, is not a painful condition.

Several studies have been performed in this area. The oldest was published in the Journal of Neuroimaging in 1991. In this study patients without low back pain underwent an MRI scan; $39 \%$ of this normal group had evidence of DDD. ${ }^{1}$ A New England Journal of Medicine article in 1994 found similar results. It showed that of 98 subjects without low back pain, 52\% had DDD on MRI. ${ }^{2}$ Similar findings were discovered in the thoracic spine (upper back) by Wood et al in the Journal of Bone and Joint Surgery in 1995. Thoracic MRI scans were performed in 90 asymptomatic adults; $73 \%$ of these patients had DDD at at least one level. ${ }^{3}$ Similar findings have been found in the radiographic analysis of asymptomatic cervical spines, with the prevalence of DDD increasing with age. In addition, MRI has been found to have high false negative and positive rates for predicting painful discs in this area. ${ }^{4}$
If DDD is not painful, then why do MRI scans and $x$ ray examinations of people with spinal pain often show DDD? The reason is probably that DDD can predispose a patient to a painful spinal condition. Important clues can be gleaned from recent research showing that painful discs have nerve in-growth. ${ }^{5}$ Additional research has shown that degenerated discs move abnormally and this property may predispose them to injury in a traumatic event. ${ }^{6}$ Finally, we have much to learn about the cause of axial spinal pain, but it seems clear that MRI scans and $x$ ray examinations are often not sufficiently sensitive to show us the cause.

Attribution is yet another problem. For instance, if a patient has evidence on examination of a right sided L 5 radiculopathy, then looking for right sided L5-S1 disease may be fruitful. However, the converse is problematic. If the patient has DDD of the right L5-S I area on an old low back $x$ ray but clearly has no symptoms or signs of this disorder on examination, then we must assume the problem had not yet reached the point of being symptomatic.

In summary, DDD as seen on $x$ ray examination and MRI scans is not a painful condition, therefore evidence of this "disorder" before an accident or injury does not mean that the patient had a painful pre-existing condition. Although it is true that some patients with DDD do have pain, it is also true that many patients without DDD have pain. Furthermore, high percentages of the normal, pain-free population have DDD. From the peer reviewed research in this area, DDD seems to be a normal part of the aging process and not "smoking gun" evidence of a pre-existing problem. 


\section{Authors' affiliations \\ C J Centeno, J Fleishman, The Centeno Clinic, Westminster, Colorado, USA}

Correspondence to: $\mathrm{Dr} C \mathrm{~J}$ Centeno, The Centeno Clinic, 11080 Circle Point Road, Building 2, Suite 140, Westminster, CO 80020, USA; centenooffice@centenoclinic.com

Accepted 8 August 2002

\section{REFERENCES}

1 Greenberg JO, Schnell RG. Magnetic resonance imaging of the lumbar spine in asymptomatic adults. Cooperative study-American Society of Neuroimaging. J Neuroimaging 1991;1:2-7.
2 Jensen MC, Brant-Zawadzki MN, Obuchowski N, Modic MT, Malkasian D, Ross JS. Magnetic resonance imaging of the lumbar spine in people without back pain. N Engl J Med 1994;331:69-73.

3 Wood KB, Garvey TA, Gundry C, Heithoff KB. Magnetic resonance imaging of the thoracic spine. Evaluation of asymptomatic individuals. J Bone Joint Surg Am 1995;77:1631-8.

4 Parfenchuck TA, Janssen ME. A correlation of cervical magnetic resonance imaging and discography/computed tomographic discograms. Spine 1994; 19:2819-25.

5 Coppes MH, Marani E, Thomeer RT, Groen GJ. Innervation of "painful" lumbar discs. Spine 1997;22:2342-9; discussion 2349-50.

6 Mimura M, Panjabi MM, Oxland TR, Crisco JJ, Yamamoto I, Vasavada A. Disc degeneration affects the multidirectional flexibility of the lumbar spine. Spine 1994;19:1371-80.

\title{
Tuberculous tonsillitis in a patient receiving etanercept treatment
}

\author{
C T Derk, R J DeHoratius
}

$\mathrm{S}$ ince the approval by the Food and Drug Administration (FDA) of tumour necrosis factor $\alpha$ antagonists, infections have accounted for $21 \%$ of the adverse events reported to the FDA for etanercept and $20 \%$ of those reported for infliximab. ${ }^{12}$

As of May 2001, from approximately 147000 subjects receiving infliximab treatment, 70 patients have been reported to have developed active tuberculosis. Of these, $52 \%$ presented with extrapulmonary tuberculosis while $24 \%$ presented with disseminated disease. ${ }^{3}$ As of April 2001, from approximately 102000 subjects receiving etanercept treatment, nine patients have been reported to have developed active tuberculosis. ${ }^{4}$ With the case report presented herein we want to add evidence to suggest that atypical presentation of active tuberculosis may also be seen in patients receiving etanercept treatment.

\section{CASE REPORT}

The patient, a 56 year old Filipino man with no significant past medical history other than receiving BCG immunisation at age 23 before he emigrated to the United States, presented to our clinic for a third opinion for his polyarthritis symptoms. He had initially been seen two years previously by a rheumatologist for left knee swelling and diffuse asymmetric arthralgias. A raised erythrocyte sedimentation rate and a raised rheumatoid factor prompted a diagnosis of rheumatoid arthritis. Treatment was started with a tapering dose of prednisone and weekly oral methotrexate. The patient discontinued both drugs about two months later and sought the advise of another rheumatologist about a year later. At that time it was noted that the patient had swelling of his wrists, ankles, and knees, and etanercept was started for a presumptive diagnosis of rheumatoid arthritis. No radiological studies were performed.

About a week before our evaluation the patient had developed a swollen left tonsil and was evaluated by an otolaryngologist, who performed a resection of his left tonsil to rule out a possible malignancy or infection.

On physical examination there was evidence of small bilateral knee effusions as well as an erythematous rash over his upper arms. There were no palpable nodules and he complained of morning stiffness that lasted for about $10 \mathrm{~min}$ utes. He had no respiratory complaints and his lung fields were clear to auscultation. Radiographic studies of his hands, wrists, and knees showed osteoarthritic changes without erosions or periarticular osteopenia. A diagnosis of inflammatory osteoarthritis was made, and the patient was treated with hydroxychloroquine $200 \mathrm{mg}$ twice daily, while etanercept was discontinued because of the new diagnosis, and also because stains of the left tonsil had shown acid fast bacilli. Antituberculous treatment was initiated by a consulting infectious disease specialist once disseminated disease was ruled out.

\section{DISCUSSION}

Two issues come to the forefront with this case. Even though biological agents are new treatments for rheumatoid arthritis, the increased incidence of infectious adverse events, should make us reserve these treatments for patients who meet the clinical criteria for a diagnosis of rheumatoid arthritis. Also of importance, and as described in this case report, is the fact that not only patients receiving infliximab but also patients receiving etanercept can have atypical presentations of Mycobacterium tuberculosis infections.

\section{Authors' affiliations}

C T Derk, R J DeHoratius, Department of Rheumatology, Thomas Jefferson University, Room 613, Curtis Bldg, 1015 Walnut Street,

Philadelphia, PA 19107, USA

Correspondence to Dr C T Derk; bacfe31@aol.com

Accepted 28 August 2002

\section{REFERENCES}

1 Gershon SK, Wise RP, Niu MT, Siegel JN. Postlicensure reports of infection during use of etanercept and infliximab. Rockville MD: Center for Biologics Evaluation and Research (CBER), FDA, 2001.

2 Keane J, Gershon S, Wise RP, Mirabile-Levens E, Kasznica J, Schwieterman WD, et al. Tuberculosis associated with infliximab, a tumor necrosis factor a-neutralizing agent. N Engl J Med 2001;345:1098-104.

3 Anonymous. Safety update on TNF-a antagonists: infliximab and etanercept. Rockville MD: Center for Biologics Evaluation and Research (CBER), FDA, 2001

4 Wallis WJ, Burge DJ, Sabath D, Gardiner M. Tuberculosis reports with etanercept (Enbrel) therapy [abstract]. Arthritis Rheum $2001 ; 44$ (suppl):S78. 


\title{
Successful treatment of resistant giant cell arteritis with etanercept
}

\author{
A L Tan, J Holdsworth, C Pease, P Emery, D McGonagle
}

Ann Rheum Dis 2003;62:373-374

G iant cell arteritis (GCA) is a systemic medium to large cell vasculitis that predominantly affects the elderly population. ${ }^{1}$ Initial high dose corticosteroids are the cornerstone of treatment, which is subsequently tapered. ${ }^{2}$ However, disease flares are not uncommon and corticosteroid related side effects are frequent. ${ }^{3}$

The limitations of corticosteroids in the treatment of some cases of GCA have led to the evaluation of other strategies using steroid sparing agents. ${ }^{4-7}$ In two previous studies patients with resistant GCA were treated with infliximab, a monoclonal chimeric antibody directed against tumour necrosis factor $\alpha$ (TNF $\alpha)$ that binds circulating and membrane bound TNF, with promising results. ${ }^{67}$ The rationale for this approach was that the vasculitic lesions in GCA had prominent macrophage infiltration where excess TNF $\alpha$ production had been demonstrated by immunohistochemistry. ${ }^{8}$

We report the case of a patient who was treated with the anti-TNF $\alpha$ agent etanercept, which is the fusion protein of the extracellular ligand binding portion of the p75 TNF receptor and the Fc portion of IgGl, on the basis that the GCA could not be controlled and that complications of high dose corticosteroid treatment appeared imminent.

\section{CASE REPORT}

The patient was an 80 year old man whose initial symptoms in March 2001 were diffuse aching of the shoulders, arms, and legs, profound morning stiffness with no headaches but a high $\mathrm{C}$ reactive protein $(\mathrm{CRP})$ of $77 \mathrm{mg} / \mathrm{l}$. Treatment was started with prednisolone $15 \mathrm{mg}$ daily with a moderate clinical improvement in the following months, but his inflammatory markers remained high. He subsequently developed headaches and was referred to the rheumatology department in May 2001. He had temporal tenderness in addition to his original symptoms; a temporal artery biopsy was therefore performed. The biopsy failed to confirm arteritis and a diagnosis of GCA was hence made based on the clinical findings. His steroids were increased to $60 \mathrm{mg}$ daily with improvement of his headaches and inflammatory markers (erythrocyte sedimentation rate (ESR) $21 \mathrm{~mm} / \mathrm{lst}$ h, CRP $12 \mathrm{mg} / \mathrm{l}$ ) (fig 1). Treatment was also started with prophylactic alendronate $70 \mathrm{mg}$ weekly together with calcium and vitamin D. Over the following six months his prednisolone could not be tapered below $20 \mathrm{mg}$ daily.

In November 2001 he had a transient ischaemic attack with sudden onset weakness in the left arm which occurred when his ESR was $84 \mathrm{~mm} / \mathrm{lst}$ h. His blood pressure, pulse, lipids, and
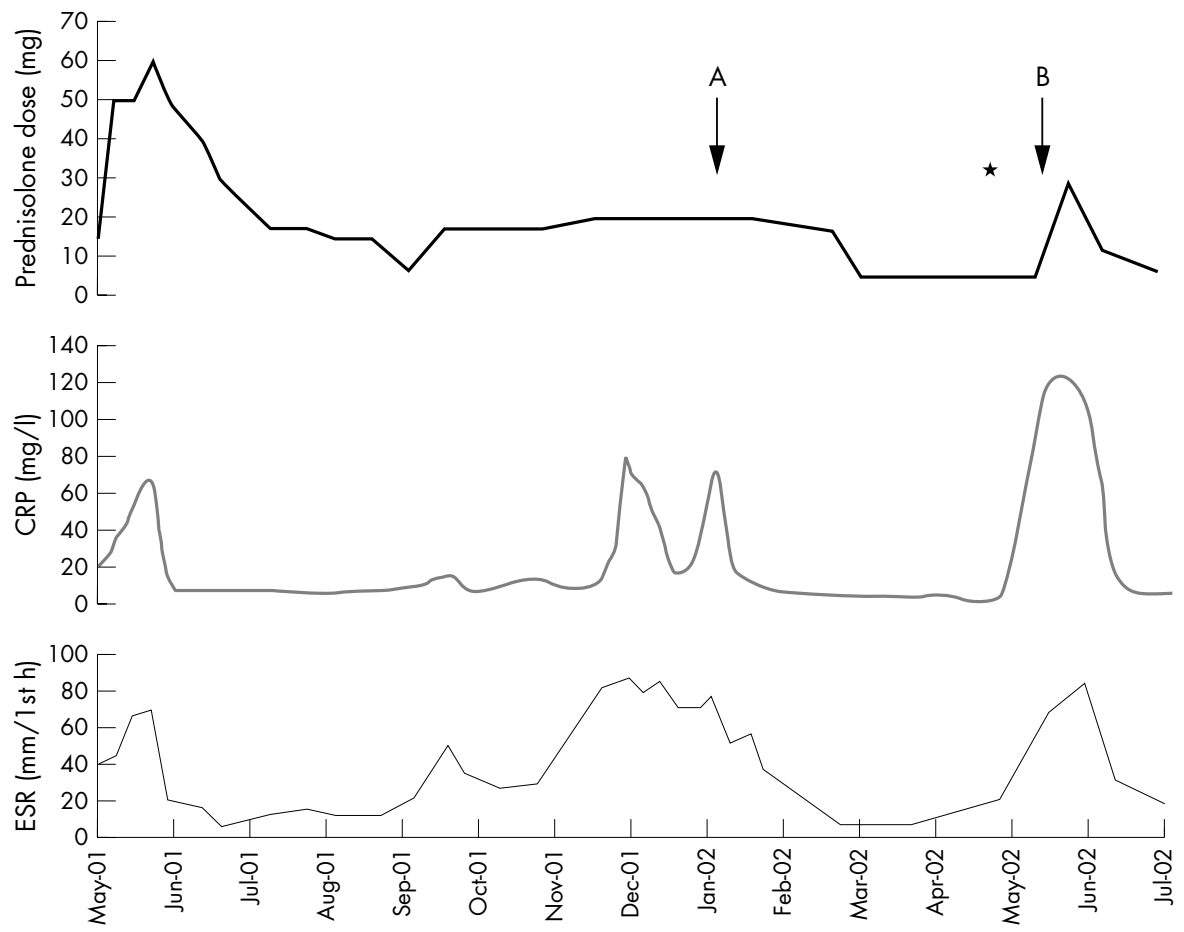

Figure 1 The effect of etanercept on $C$ reactive protein (CRP) and erythrocyte sedimentation rate (ESR) of the patient. Etanercept treatment was started at point $\mathrm{A}$, when symptoms were uncontrolled with prednisolone $20 \mathrm{mg}$ daily, at a stage when the patient had visual symptoms. The patient improved and was able to reduce the dose of the steroid. He discontinued the etanercept in May 2002 and consequently his disease flared (shown by the asterisk). The recurrence of his initial GCA symptoms coupled with an increase of his inflammatory markers prompted us to restart the etanercept treatment (point B). He responded well, the inflammatory markers fell and the dose of prednisolone was quickly tapered to $7.5 \mathrm{mg} /$ day. 
electrocardiograph were normal, and this episode was attributed to the arteritis. An insufficiency fracture was also suspected when he developed severe rib pain after coughing. He had a pre-existing history of macular degeneration and glaucoma and had complained of gradual visual deterioration during high dose corticosteroid treatment. No change in visual acuity was demonstrated and his intraocular pressures were normal. His blood glucose was also normal.

In view of the persistently high dose of steroids used, the failure to suppress the inflammation, the complications, and the concern about the steroids contributing to normal pressure glaucoma, the patient was offered etanercept in February 2002. Treatment was started with $25 \mathrm{mg}$ subcutaneously twice weekly and he continued to receive prednisolone $20 \mathrm{mg}$ daily. Within the following month there was a dramatic resolution of the myalgia and stiffness around his shoulders, arms, neck, and thighs. His corticosteroid dose was tapered to $5 \mathrm{mg}$ daily and the frequency of etanercept was decreased to once every eight days.

The patient, thinking that he was cured, stopped taking the etanercept. Two weeks after he stopped he contacted the rheumatology department with a severe flare of his disease (ESR $71 \mathrm{~mm} / \mathrm{lst}$ h, CRP $123 \mathrm{mg} / \mathrm{l}$ ) and return of the symptoms he had before the initial treatment with etanercept. Treatment was therefore restarted with etanercept without adjusting his steroid dose initially. No immediate response was evident so the prednisolone was increased to $30 \mathrm{mg}$ daily two weeks later, and his symptoms resolved within one month with associated normalisation of his ESR and CRP. Six months after starting etanercept he is maintained on a dose of $25 \mathrm{mg}$ every four days and prednisolone $5 \mathrm{mg}$ and $7.5 \mathrm{mg}$ on alternate days.

\section{DISCUSSION}

TNF $\alpha$ is a proinflammatory cytokine with a pivotal role in the pathogenesis of GCA. ${ }^{89}$ As far as we know, this is the first report suggesting that etanercept may have a role in the treatment of resistant GCA. This single case does not allow us to draw definitive conclusions from our observation. Nevertheless, the dramatic responses following treatment, the flare of disease on discontinuation, and the successful re-induction of remission suggest that etanercept might be useful in resistant GCA. We noted that remission induction was delayed and that relatively high dose corticosteroids had to be given when etanercept was started, but that this could be quickly tapered in the following weeks. The advantage of etanercept as a steroid sparing agent in GCA is the ease of administration and the ability to taper the dose depending on clinical and laboratory responses. Further studies are warranted to determine the efficacy of etanercept in resistant GCA.

\section{Authors' affiliations}

A L Tan, C Pease, P Emery, D McGonagle, Department of Rheumatology, Leeds General Infirmary, Great George Street, Leeds LS1 3EX, UK

A L Tan, J Holdsworth, D McGonagle, Department of Rheumatology,

Calderdale Royal Hospital, Salterhebble, Halifax HX3 OPW, UK

Correspondence to: Dr D McGonagle; d.g.mcgonagle@leeds.ac.uk

Accepted 16 December 2002

\section{REFERENCES}

1 Salvarani C, Cantini F, Boiardi L, Hunder GG. Polymyalgia rheumatica and giant-cell arteritis. N Engl J Med 2002;347:261-71.

2 Hunder GG. Giant cell arteritis and polymyalgia rheumatica. Med Clin North Am 1997:81:195-219.

3 Gabriel SE, Sunku J, Salvarani C, O'Fallon WM, Hunder GG. Adverse outcomes of antiinflammatory therapy among patients with polymyalgia rheumatica. Arthritis Rheum 1997;40:1873-8.

4 van der Veen MJ, Dinant HJ, van Booma-Frankfort $C$, van Albada-Kuipers GA, Biilsma JW. Can methotrexate be used as a steroid sparing agent in the treatment of polymyalgia rheumatica and giant cell arteritis? Ann Rheum Dis 1996;55:218-23.

5 DeSilva M, Hazleman BL. Azathioprine in giant cell arteritis/ polymyalgia rheumatica: a double blind study. Ann Rheum Dis 1986:45:136-8

6 Cantini F, Niccoli L, Salvarani C, Padula A, Olivieri I. Treatment of longstanding active giant cell arteritis with infliximab: report of four cases. Arthritis Rheum 2001;44:2933-5.

7 Airo P, Antoniolo CM, Vianelli M, Toniati P. Anti-tumour necrosis factor treatment with infliximab in a case of giant cell arteritis resistant to steroid and immunosuppressive drugs. Rheumatology (Oxford) 2002;41:347-9.

8 Field M, Cook A, Gallagher G. Immuno-localisation of tumor necrosis factor and its receptors in temporal arteritis. Rheumatol Int 1997:17:113-18.

9 Goronzy JJ, Weyand CM. Cytokines in giant-cell arteritis. Cleve Clin J Med 2002;69(suppl 2):SII91-4.

\section{Bilateral subdural effusion in a patient with neuro-Behçet's disease}

\section{N Suzuki, M Takeno, G Inaba}

$\mathrm{T}$ he central nervous system is sometimes affected in patients with Behçet's disease. ${ }^{1}$ Meningoencephalitis and brainstem lesions are the most common problems. The appearance of subdural effusion has been rarely reported. Our patient, who had neuro-Behçet's disease with massive bilateral subdural effusion, was successfully treated with steroid pulse therapy.

\section{CASE REPORT}

The patient (a 45 year old man) first developed polyarthralgia, fever, recurrent oral aphthosis, and headache in 1986. In 1987 he had a genital ulcer and positive pathergy test. Thus, he ful- filled the international criteria for the diagnosis of Behçet's disease. He had two cycles of steroid pulse therapy, and his symptoms including headache subsided. In 1995 an episodic exacerbation of the neuro-Behçet's disease occurred, accompanying parkinsonism and abnormal cerebral spinal fluid (CSF) findings (cell 5/3, protein $0.97 \mathrm{~g} / \mathrm{l}$, IgG $0.07 \mathrm{~g} / \mathrm{l}$ ). The symptoms improved after treatment with prednisolone 40 $\mathrm{mg} /$ day + colchicine $1 \mathrm{mg} /$ day.

In December 2000 he began to have severe oral aphthosis and folliculitis, even though he had been taking low doses of steroids + colchicine. On 4 January 2001 he was admitted to our hospital because of fever $\left(38-39^{\circ} \mathrm{C}\right)$, steppage gait, 

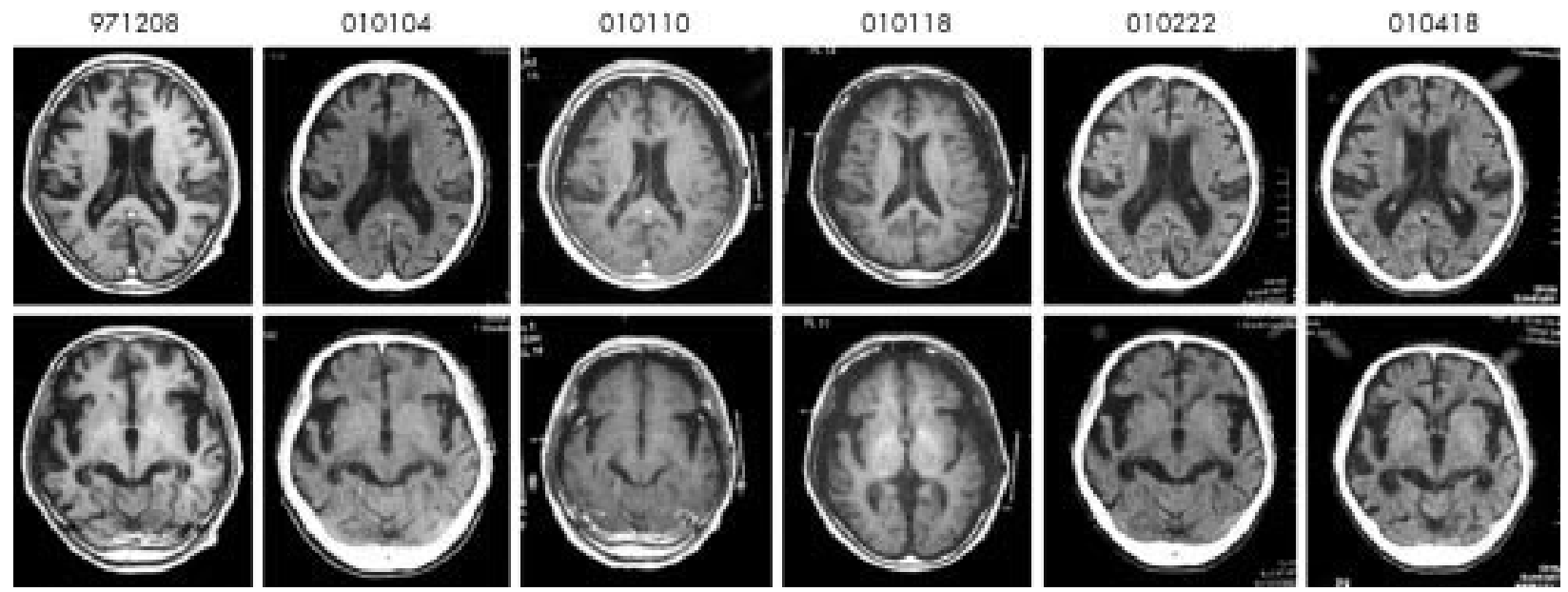

Figure 1 MRI ( $T_{1}$ weighted image) of the patient. Subdural effusion first appeared in 010110 and disappeared in 010222.

headache, and intentional tremor. Physical examination also disclosed mild rigidity (bilateral), dysarthria, poor fingernose-finger test, poor heel-knee test, Kernig sign (-), and nuchal rigidity $(-)$. No focal sign was evident. On admission, his white blood cell count was $8.8 \times 10^{9} / 1$, erythrocyte sedimentation rate $22 \mathrm{~mm} / \mathrm{lst} \mathrm{h}, \mathrm{C}$ reactive protein $81 \mathrm{mg} / \mathrm{l}$, and serum IgD $21 \mathrm{mg} / \mathrm{l}$. Other laboratory examinations of blood and urine, including antivirus antibodies were normal. The CSF showed: cell 18/3 (mononuclear cells 14, polymorphonuclear cells 4), protein $430 \mathrm{mg} / \mathrm{l}$, glucose $3.1 \mathrm{mmol} / \mathrm{l}, \mathrm{Cl} 105 \mathrm{mEq} / \mathrm{l}$. An electroencephalogram was almost normal. Magnetic resonance imaging (MRI) at 010104 disclosed no interval change as compared with MRI at 971208 (mild brain atrophy only) (fig l).

We first suspected infection as the origin of his symptoms, but he did not respond to antibiotics. MRI at 010110 showed the sudden appearance of bilateral subdural effusion. The effusion was iso-intensity at $\mathrm{T}_{1}$ weighted image and high intensity at $\mathrm{T}_{2}$ weighted image, suggesting exudate or transudate. We made a diagnosis of exacerbation of neuro-Behçet's disease, and gave methylprednisolone $250 \mathrm{mg}$ /day for three days followed by oral prednisolone $40 \mathrm{mg} /$ day. Thereafter, the subdural effusion disappeared (MRI at 010222 and 010418). His neurological symptoms, including ataxia and dysarthria, gradually improved. His condition is being managed in the outpatient clinic and he has improved and his neurological symptoms have remained stable until now.

\section{DISCUSSION}

Bacterial meningitis of childhood sometimes accompanies subdural effusion. ${ }^{2}$ Because no direct infectious cause was shown by the laboratory tests, and steroid pulse therapy was effective, we suggest that the finding was due to neuroBehçet's disease. Previous studies have shown both a lymphocytic or neutrophilic meningoencephalitis and multifocal necrotic foci, predominantly in the brainstem and basal ganglion region, as the pathology of the central nervous system involvement. ${ }^{13}$ i Bilateral subdural effusion in patients with neuro-Behçet's disease is a rare complication of this disease. $^{3-8}$
It is not always easy to distinguish exacerbation of the inflammatory disease from infection. However, the pathology of Behçet's disease is generally considered to be vasculitis of small vessels, and differences in the symptoms may reflect the differences of the affected vessels. ${ }^{19}$ Thus, possibly, transient subdural venulitis led to the appearance of subdural effusion in this patient, and steroid pulse therapy brought about improvement of the subdural effusion. This case further emphasises the wide spectrum of neurological manifestations of Behçet's disease.

\section{Authors' affiliations}

N Suzuki, M Takeno, Departments of Immunology and Medicine, St Marianna University School of Medicine

G Inaba, Department of Ophthalmology, Uveitis Clinic, Tokyo Women's Medical College, Daini Hospital

Correspondence to: Dr N Suzuki, Departments of Immunology and Medicine, St Marianna University School of Medicine, 2-16-1, Sugao, Miyamae-ku, Kawasaki, Kanagawa 216-8511, Japan;

n3suzuki@marianna-u.ac.jp

Accepted 12 August 2002

\section{REFERENCES}

1 Sakane T, Takeno M, Suzuki N, Inaba G. Behçet's disease. N Engl J Med 1999;341:1284-91.

2 Daoud AS, Zaki M, al-Saleh QA. Prolonged and secondary fever in childhood bacterial meningitis. Eur J Pediatr 1989;149:114-16.

3 Akman-Demir G, Serdaroglu P, Tasci B. Clinical patterns of neurological involvement in Behçet's disease: evaluation of 200 patients. The Neuro-Behçet Study Group. Brain 1999;122:2171-82.

4 Siva A, Kantarci OH, Saip S, Altintas A, Hamuryudan V, Islak C, et al. Behçet's disease: diagnostic and prognostic aspects of neurological involvement. J Neurol 2001;248:95-103.

5 Gerber S, Biondi A, Dormont D, Wechsler B, Marsault C. Long-term MR follow-up of cerebral lesions in neuro-Behçet's disease. Neuroradiology 1996;38:761-8.

6 Kidd D, Steuer A, Denman AM, Rudge P. Neurological complications in Behçet's syndrome. Brain 1999; 122:2183-94.

7 Siva A, Fresko II. Behçet's disease. Curr Treat Options Neurol 2000;2:435-48.

8 Lee SH, Yoon PH, Park SJ, Kim DI. MRI findings in neuro-Behçet's disease. Clin Radiol 2001:56:485-94.

9 Kocer N, Islak C, Siva A, Saip S, Akman C, Kantarci O, et al. CNS involvement in neuro-Behçet syndrome: an MR study. AJNR Am J Neuroradiol 1999;20:1015-24. 


\title{
A case of multiple sclerosis associated with rheumatoid arthritis and positive anticardiolipin antibodies
}

\author{
S Mpofu, R J Moots
}

Ann Rheum Dis 2003;62:376

W e describe the case of a 59 year old man with longstanding multiple sclerosis (MS) since his early fifties, who after many years developed the clinical and serological manifestations of erosive rheumatoid arthritis (RA). This rare association is interesting owing to the overlapping pathophysiological similarities of $\mathrm{T}$ cell and tumour necrosis factor $\alpha(\mathrm{TNF} \alpha)$ in both diseases. ${ }^{12}$ The MS musculoskeletal complaints masked proper assessment of his RA, resulting in a delayed diagnosis. As far as we know, this is the first case in which MS, RA, and serum anticardiolipin antibodies ( $\mathrm{aCL}$ ) have been found to be present simultaneously.

\section{CASE REPORT}

A 48 year old man presented to the orthopaedic clinic with left knee and foot pain and an associated mild weakness on the left side. Examination confirmed patellofemoral crepitus, and spastic paraparesis. A diagnosis of MS was made, supported by oligoclonal bands in cerebral spinal fluid, delayed visual evoked responses, and magnetic resonance imaging studies which showed high intensity areas in the brainstem tegmentum and periventricular white matter. His main deficit was spasticity of the legs and intermittent pains in hands and feet. He was mobile with crutches. Baclofen or dantrolene in therapeutic doses did not improve his spasticity.

Eight years later, aged 56, he developed a flitting symmetrical polyarthritis that was relieved by ibuprofen. There were no extra-articular manifestations of RA; he had two hours of early morning stiffness. There was no active synovitis on musculoskeletal examination. Acute phase proteins, full blood count, biochemistry, rheumatoid factor, antinuclear antibody, and extranuclear antibodies were all normal. IgG aCL was 30.3 GPLU, and it remained raised on repeated occasions. He continued to have episodic joint swelling and pain in both feet and hands, without synovitis or serological abnormalities at each review for four years. Feet and hands $x$ ray examinations carried out at age 57 were normal. At age 59, he presented with swollen metacarpophalangeal (MCP) joints and painful feet, with almost total loss of mobility and independence. He had evident MCP, right wrist and metatarsophalangeal (MTP) synovitis. Feet and hand $x$ ray examinations showed well marked periarticular osteoporosis and erosive arthropathy. Investigations showed an erythrocyte sedimentation rate of $50 \mathrm{~mm} / \mathrm{lst}$ h, C reactive protein $44 \mathrm{mg} / \mathrm{l}$, and rheumatoid factor negative; biochemistry and full blood count were normal, and IgG aCL was 35.6 GPLU. Treatment was started with methotrexate, folic acid, and low dose aspirin, with great improvement in his joint swelling, mobility, and acute phase response.

\section{DISCUSSION}

TNF $\alpha$ and T cells drive the inflammatory cytokine cascade that activates metalloproteinases and other degradative enzymes, thus leading to erosive joint destruction in RA and demyelisation in MS. ${ }^{3}$ A bibliographic search to date has confirmed that no reports exist which suggest either an increased incidence or prevalence of RA in patients with MS. This case suggests that regardless of the absence of synovitis and an initial raised acute phase response, a history suggestive of inflammatory joint disease should lead to further evaluations and close follow up to avoid delayed diagnosis of RA and treatment. The concomitant occurrence of reduced activities of daily living and the predominance of longstanding foot pain masked proper evaluation of MTP synovitis.

The opposite is also true, that MS diagnosis can be delayed in patients with active RA, further highlighting the possibility that most of the reported cases of demyelinating process in patients with RA treated with $\mathrm{TNF} \alpha$ antagonist represent exacerbation of a pre-existing state of early MS. ${ }^{45}$

The relevance of persistently raised aCL in our patient is of clinical interest as he developed RA later in life. It is well recognised that aCL in patients with MS indicate an underlying autoimmune disease or an epiphenomenon of a more diffuse immunological process. ${ }^{6}$ It is also apparent that aCL have no influence on MS progression. Roussel et al found no correlation between aCL and age, sex, duration of MS from diagnosis, category of MS, clinical course, clinical symptoms, serum levels, or atypical lesions by magnetic resonance imaging. ${ }^{7}$ Hence, aCL as in this case, did not influence or change the clinical form of MS.

In conclusion, our report highlights the interesting association between MS and RA. It emphasises the need to consider this potential rare association to avoid delayed diagnosis of RA in patients with MS.

\section{Authors' affiliations \\ S Mpofu, R J Moots, University Hospital Aintree, Academic Rheumatology Unit, Liverpool L9 7AL, UK}

Correspondence to: Dr S Mpofu; tsujoy@aol.com

Accepted 25 July 2002

\section{REFERENCES:}

1 Kollias G, Douni E, Kassiotis G, Kontoyiannis D. The function of tumour necrosis factor and receptors in models of multi-organ inflammation, rheumatoid arthritis, multiple sclerosis and inflammatory bowel disease. Ann Rheum Dis 1999;58(suppl 1):132-9.

2 Adorini L, Bonneville M, Kollias $G$. Pathogenic and protective T-cell responses in autoimmune diseases. Res Immunol 1998;149:873-5.

3 Kassiotis G, Baver J, Akassoglou K, Lassmann H, Kollias G, Probert L. A tumor necrosis factor-induced model of human primary demyelinating diseases develops in immunodeficient mice. Eur J Immuno 1999;29:912-17.

4 Robinson WH, Genovese MC, Moreland LW. Demyelinating and neurologic events reported in association with tumour necrosis factor alpha antagonism: by what mechanisms could tumour necrosis factor alpha antagonists improve rheumatoid arthritis but exacerbate multiple sclerosis? Arthritis Rheum 2001;44:1977-83.

5 Mohan N, Edwards ET, Cupps TR, Oliverio PJ, Sandberg G, Crayton H, et al. Demyelination occurring during anti-tumour necrosis factor alpha therapy for inflammatory arthritides Arthritis Rheum 2001;44:2862-9.

6 de Andres C, Guillem A, Rodriguez-Mahou M, Lopez Longo FJ. Frequency and significance of anti-Ro (SS-A) antibodies in multiple sclerosis patients. Acta Neurol Scand 2001;104:83-7.

7 Roussel V, Yi F, Jauberteau MO, Couderg C, Lacombe C, Michelet V, et al. Prevalence and clinical significance of anti-phospholipid. J Autoimmun 2000;14:259-65. 


\title{
Observation on serum anti-double stranded DNA antibodies of tripterine in systemic lupus erythematosus of $(\mathrm{NZB} \times \mathrm{W}) \mathrm{F} 1$ mice
}

\author{
X Xu, Z Wu, C Xu, Y Ren, Y Ge
}

Ann Rheum Dis 2003;62:377-378

$\mathrm{T}$ ipterine is one of the major active components isolated from the traditional Chinese herb Tripterygium wilfordii Hook. f. Previous studies have shown that tripterine inhibits not only humoral and cellular immune responses but also the inflammatory response. ${ }^{1}$

This study aimed at exploring the inhibitory effects of tripterine on lupus nephritis. We studied the effect of tripterine in $(\mathrm{NZB} \times \mathrm{W}) \mathrm{Fl}$ mice, who spontaneously develop autoimmune disease characterised by the production of dsDNA antibodies and the development of a severe immune complex glomerulonephritis, like in human lupus nephritis. ${ }^{23}$ The dsDNA antibodies are thought to have a role in the pathogenesis of mouse lupus-like nephritis. ${ }^{4}$ Raised levels of circulating anti-dsDNA antibodies often precede the development of nephritis. ${ }^{56}$

$(\mathrm{NZB} \times \mathrm{W}) \mathrm{F} 1$ female mice, 2 months of age at the start of the experiment, were used in these studies. All animals were housed at constant temperature and fed a standard diet. The mice were evaluated for proteinuria every two weeks using the Coomassie blue $\mathrm{G}$ dye binding assay. ${ }^{7}$ After starting treatment all mice were housed in metabolic cages, and 24 hour urinary protein was collected for determination of basal urinary protein excretion levels. Levels $>3 \mathrm{mg} /$ day during the subsequent follow up were considered abnormal. ${ }^{8}$ Blood was collected from the ophthalmic venous plexa for determination of the packed cell volume, and the serum was stored at $-20^{\circ} \mathrm{C}$; serum anti-dsDNA antibody levels were measured by enzyme linked immunosorbent assay (ELISA) ${ }^{9}$ before treatment and then every two weeks. Twenty four hour urine samples were collected for determination of basal urinary protein excretion. The $(\mathrm{NZB} \times \mathrm{W}) \mathrm{Fl}$ mice were randomly allocated to one of three groups to evaluate the therapeutic effect of tripterine on survival of the animals. Group A animals were untreated; groups $\mathrm{B}$ and $\mathrm{C}$ were given weekly intraperitoneal injections of tripterine $3 \mathrm{mg} / \mathrm{kg}$ wt and $6 \mathrm{mg} / \mathrm{kg} \mathrm{wt}$, respectively. The experiment was continued for 20 weeks.

We found that tripterine reduced the urinary protein excretion. Before treatment, animals in both groups B and C had similar concentrations of 24 hour urine protein. Untreated lupus mice (group A) at 6 weeks of age had an increased concentration of 24 hour urine protein. The mean (SD) urinary protein excretion was significantly reduced in tripterine treated groups (B and $\mathrm{C}$ ) in comparison with the control group A (mean (SD) $0.43(0.09)$ and $0.38(0.13) v 14.89$ (5.11) $\mu \mathrm{g} / \mathrm{min}, \mathrm{p}<0.001)$. There was no significant difference in proteinuria between groups $\mathrm{B}$ and $\mathrm{C}$ after eight weeks $(0.53$ (0.15) $v 0.50(0.19) \mu \mathrm{g} / \mathrm{min})$.

The levels of serum anti-dsDNA autoantibodies were evaluated every two weeks during the study (table 1). Different doses of tripterine suppressed the serum level of anti-dsDNA antibodies at different stages.

In untreated animals a rise in the level of serum dsDNA antibodies preceded the change of proteinuria at 2-4 weeks.

Our preliminary study indicates that tripterine greatly reduces the amount of urine protein excretion, suppressing the formation of serum anti-dsDNA antibodies. It ameliorates the clinical symptoms of the $(\mathrm{WZB} \times)$ Fl mice, improves their
Table 1 Serum level of anti-dsDNA antibodies at different stages in groups given different doses of tripterine in comparison with the control group (OD, mean (SD))

\begin{tabular}{llll}
\hline Weeks & A group & B group & C group \\
\hline 0 & $0.30(0.07)$ & $0.22(0.15)$ & $0.14(0.09)$ \\
2 & $0.60(0.17)$ & $0.18(0.14)^{* *}$ & $0.18(0.12)^{* *}$ \\
4 & $0.43(0.05)$ & $0.37(0.26)$ & $0.25(0.09)$ \\
6 & $0.99(0.28)$ & $0.48(0.16)^{* *}$ & $0.31(0.18)^{* * *}$ \\
8 & $0.87(0.17)$ & $0.42(0.22)^{* *}$ & $0.23(0.1)^{* * *}$ \\
10 & $0.82(0.42)$ & $0.24(0.16)^{* *}$ & $0.33(0.24)^{* *}$ \\
12 & $0.74(0.41)$ & $0.32(0.15)^{* *}$ & $0.28(0.12)^{* *}$ \\
14 & $1.18(0.48)$ & $0.32(0.13)^{* * *}$ & $0.38(0.16)^{* * *}$ \\
16 & $0.88(0.16)$ & $0.33(0.10)^{* *}$ & $0.22(0.09)^{* * *}$ \\
18 & $1.58(0.35)$ & $0.31(0.11)^{* * *}$ & $0.23(0.10)^{* * *}$ \\
20 & & $0.30(0.07)^{*}$ & $0.25(0.09)$ \\
\hline
\end{tabular}

Note: In the groups treated with tripterine ( $B$ and $C$ groups) in comparison with the control group (A). ${ }^{* *} p<0.01 ;{ }^{* * *} p<0.001$

survival rate, and has a definite protective effect on lupus nephritis. These results suggest that clinical studies should be carried out to explore the exciting possibility that tripterine might be used in the treatment of human lupus.

\section{ACKNOWLEDGEMENTS}

This study was supported by grant 97401910 item from the Shanghai Science and Technology Committee Foundation.

We thank Professor De-Chen Zhang, Department of Pharmacology, Institute of Material Medica, Fudan University, for providing the tripterine.

\section{Authors' affiliations}

X Xu, Z Wu, C Xu, Y Ren, Y Ge, Division of Nephrology, Zhongshan Hospital, Fudan University, Shanghai, China

Correspondence to: $\operatorname{Dr} X X_{U}$, Division of Nephrology, Zhongshan Hospital , Fudan University, Shanghai 200032, China;

xunhuixu@hotmail.com

Accepted 23 July 2002

\section{REFERENCES}

1 Zhang LX, Yu FK, Zhang QY, Fang Z, Pan DJ. Immunosuppressive and antiinflammatory activities of tripterine. Yao Xue Xue Bao 1990:25:573-7.

2 Okamura M, Kanayama Y, Amastu K, Negoro N, Koda S, Takeda T, ef al. Significance of enzyme linked immunosorbent assay (ELISA) for antibodies to double-stranded and single-stranded DNA in patients with lupus nephritis: correlation with severity of renal histology. Ann Rheum Dis 1993;52:14-20.

3 Bootsma $\mathbf{H}$, Spronk PE, Borg EJT, Hummel EJ, Boer GD, Limburg PC, ef al. The predictive value of fluctuations in $\lg M$ and $\lg G$ class anti-dsDNA antibodies for relapses in systemic lupus erythematosus. A prospective long term observation. Ann Rheum Dis 1997:56:661-6.

4 Vyse TJ, Drake CG, Razzo ST, Lzui S, Kotzin BL. Genetic linkage of lgG autoantibody production in relation to lupus nephritis in New Zealand hybrid mice. J Clin Invest. 1996,98:1762.

5 Winkler TH, Jahn S, Lalden JR. IgG human monoclonal anti-DNA autoantibodies from patients with systemic lupus erythematosus. Clin Exp Immunol 1991;85:379-85. 
6 Ehreustein MR, Longhurst CM, Isenberg DG. Production and analysis of IgG monoclonal anti-DNA antibodies from SLE patients. Clin Exp Immunol 1993;92:39-45.

7 Read SM, Northoote DH. Minimization of variation in the response to different proteins of the Coomassie blue $\mathrm{G}$ dye-binding protein. Anal Biochem 1981;116:55-64
8 Swenaga $\mathbf{R}$, Abdou NI. Anti-(DNA-histone) antibodies in active lupus nephritis. J Rheumatol 1996;23:279-85.

9 Emlen W, Jarusiripipat P, Burdick G. A new ELISA for the detection of double-stranded DNA antibodies. J Immunol Methods 1990;132:91-102.

\section{Clodronate induced uveitis}

\section{P Fietta, P Manganelli, L Lodigiani}

W e are reporting on a 68 year old woman, treated for postmenopausal osteoporosis with clodronate, a non-nitrogen, halogen containing bisphosphonate (BP), who developed a bilateral, drug related, anterior acute uveitis. BPs are generally well tolerated. Uveitis is an ocular adverse effect hitherto described only for nitrogen containing bisphosphonates (N-BPs). ${ }^{12}$ To our knowledge, this is the first report of uveitis induced by a non-N-BP.

\section{CASE REPORT}

In April 2001 the patient presented with a three month history of spinal pain, following an accidental fall. Spine and pelvis $x$ ray examination showed osteoporotic fractures in T12, L1, and L2 vertebral bodies. Bone densitometry dual energy $x$ ray absorptiometry evaluation showed remarkably reduced mineral density in both vertebral and femoral neck sites (T score -4.3 and -4.08 , respectively). Because the patient had had reflux oesophagitis, we treated her with $100 \mathrm{mg}$ once a week of intramuscular (IM) clodronate, the only parenteral BP available for outpatients in our country. The treatment progressively reduced the spinal pain.

In August 2001 the patient started to have the first mild symptoms of a bilateral iritis, such as transient tearing, photophobia, and ocular redness, attributed by her ophthalmologist to viral infection. Thus, the clodronate treatment was continued. The patient was treated with topical corticosteroids, and the ocular problems promptly resolved. However, thereafter they regularly recurred in the 24-72 hours after each IM clodronate administration. Because the intensity and persistence of her ocular symptoms from time to time progressively worsened, in September 2001 the patient returned for our consultation. Ocular examination disclosed marked bilateral perikeratic hyperaemia, and anterior uveitis was diagnosed. Routine biochemical and inflammatory measurements were normal. Autoantibodies were negative, as well as HLA typing for the B27 antigen. The patient was treated for seven days with topical corticosteroids and cycloplegic drugs, and recovered completely. The clodronate treatment was discontinued and the ocular symptoms did not recur.

In January 2002, we rechallenged with the drug, because the patient asked for another course of treatment, but after the first IM clodronate administration, the ocular complaints started again. The patient was not taking any other drug. Thus, a bilateral anterior uveitis related to clodronate was diagnosed and the drug was permanently suspended. Thereafter, the patient was consistently symptom-free.

\section{DISCUSSION}

Ocular adverse effects have been hitherto reported only for the N-BPs risedronate, ${ }^{1}$ pamidronate, ${ }^{1}$ and alendronate. ${ }^{2}$ Interestingly, a patient previously tolerant to the non-nitrogen derivative etidronate shortly developed anterior uveitis after both oral risedronate and intravenous pamidronate, ${ }^{1}$ suggesting that the chemical structure may play a part in the pathogenesis of the eye disease. The ocular side effects have been interpreted as a consequence either of an allergic reaction or an acute inflammatory response. ${ }^{3} \mathrm{~N}$-BPs are known to cause transient pyrexia, a flu-like syndrome, and serological changes resembling a typical acute phase response, and also to stimulate the release of proinflammatory cytokines, such as tumour necrosis factor $\alpha$, interleukin 1 , and interleukin $6 .{ }^{4}$ Thus, they may act as adjuvants in an immune reaction, which might have the uvea as a target organ. Instead, clodronate inhibits proinflammatory cytokine and nitric oxide secretion from activated macrophages, especially when delivered into cells by liposomes. ${ }^{5}$ In our case, the bilateral anterior uveitis, correlated well with the parenteral clodronate administration, and might be related to an idiosyncratic reaction rather than to a cytokine mediated process.

To our knowledge, ocular adverse manifestations have not hitherto been described for the non-N-BP clodronate. Because the BPs are successfully used in an increasingly broad range of diseases, we wish to report this observation, which suggests the need for a careful evaluation of ocular symptoms developing during treatment with any BP, independently of its chemical structure.

\section{Authors' affiliations}

P Fietta, P Manganelli, Dipartimento Osteo-Articolare, Unità Operativa di Reumatologia e Medicina Interna, Azienda Ospedaliera di Parma, Italy

L Lodigiani, Unità Operativa di Oculistica, Ospedale di Asola (Mantova), Italy

Correspondence to: Dr P Manganelli, Dipartimento Osteo-Articolare, Uniłà Operativa di Reumatologia e Medicina Interna, Azienda Ospedaliera di Parma, Via Gramsci, 14, 43100 Parma, Italy; pmanganelli@ao.pr.it

Accepted 9 August 2002

\section{REFERENCES}

1 Siris ES. Bisphosphonates and iritis. Lancet 1993;341:436-7.

2 Salmen S, Berrueta L, Sanchez N, Montes H, Borges L.

Nongranulomatous anterior uveitis associated with alendronate therapy. Invest Clin 2002;43:49-52.

3 Moorthy RS, Valluri S, Jampol LM. Drug-induced uveitis. Surv Ophthalmol 1998;42:557-70.

4 Thiebaud D, Sauty A, Burckhardt P, Leuenberger P, Sitzler L, Green JR, et al. An in vitro and in vivo study of cytokines in the acute-phase response associated with bisphosphonates. Calcif Tissue Int 1997;61:386-92

5 Makkonen N, Salminen A, Rogers M, Frith JC, Urtti A, Azhayeva E, et al. Contrasting effects of alendronate and clodronate on RAW 264 macrophages: the role of a bisphosphonate metabolite. Eur J Pharm Sci 1999;8:109-18. 


\title{
Aminotransferase levels during treatment of rheumatoid arthritis with leflunomide in clinical practice
}

\author{
A Hoi, G O Littlejohn
}

Ann Rheum Dis 2003;62:379

eflunomide is a disease modifying drug with proven efficacy in the treatment of rheumatoid arthritis (RA). ${ }^{1-6}$ LClinical trials have indicated that low level, reversible, asymptomatic increases in serum transaminases may occur, although serious hepatotoxicity is uncommon. ${ }^{6-8}$ It remains unclear as to whether the characteristics of leflunomide transaminitis, reported in clinical trials, occur in a less vigorously monitored and clinically heterogeneous normal care RA population.

\section{METHODS AND RESULTS}

Between November 1999 and September 2001 we audited all non-hospital clinic patients with RA, privately managed with leflunomide by one physician (GOL), for the frequency and severity of transaminitis. These patients received usual care and were felt to be more likely to have other comorbidities, polypharmacy, and poorer review compliance than clinical trial patients.

Serum alanine aminotransferase (ALT) levels are reported, as they were the only transaminase determined by the each of the four regional laboratories which took part in monitoring the geographically widespread patients as part of their liver function test panel. One hundred consecutive patients were followed up prospectively for a mean of nine months. The mean number of previous disease modifying antirheumatic drugs (DMARDs) was 3.65, the patients' mean age was 56 years and mean disease duration was 14 years. Sixty three per cent of patients received leflunomide added to methotrexate. Blood tests were usually performed monthly to three monthly. When ALT levels were significantly abnormal, management depended on which combination of DMARDs the patient was taking, the timing of the abnormality, the pre-leflunomide ALT characteristics, and the clinical response to leflunomide.

Ninety five per cent of increases occurred in the first 270 days of observation. Thirty per cent of patients had at least one episode of a raised ALT level above the individual laboratory upper limit of normal (ULN). Of these, 21/30 (79\%) had levels less than twice the ULN, while 4/30 (13\%) had levels more than three times the ULN. Six patients had abnormal ALT levels on more than three occasions. All patients with severe or frequent ALT abnormality were receiving a methotrexate/ leflunomide combination, with one discontinuing leflunomide. Of the rest, all ALT levels returned to normal with observation or reduction in the dose of methotrexate (if used in combination) or leflunomide. No patient had symptoms of liver toxicity or required a washout procedure.

The mean level of serum ALT over the next three months did not vary significantly whether a leflunomide loading dose was used or not. The mean ALT level in 35 randomly selected patients receiving a methotrexate/leflunomide combination was $78.6 \%$ of the ULN compared with $51.2 \%$ when receiving methotrexate monotherapy in the two previous years $(\mathrm{p}<0.0001)$, although both were still within the normal range.

\section{DISCUSSION}

This group of patients had severe recalcitrant RA as shown by the long duration of the disease and the high number of previous DMARDs. In this study we report ALT levels, which are generally more sensitive to change than aspartate aminotransferase
(AST), to show minor changes in these patients with RA treated with leflunomide in routine clinical practice similar to those seen under more rigorous clinical trial conditions. ${ }^{1-8}$ The combination of leflunomide and methotrexate led to all of the significant rises in ALT. However, the low level of the highest increases and the return to normal with observation or dose modification, particularly of methotrexate if used in combination, is reassuring to the clinician, who is used to minor fluctuations in ALT/AST in methotrexate monitoring programmes. Currently in patients with RA taking methotrexate, serum transaminase levels, particularly AST, are the best surrogate marker and predictor of clinically significant liver disease..$^{-11}$

Although this study reflects "real world" rather than rigid clinical trial patient characteristics and monitoring, it is short term and further observation over time is required to evaluate clinically significant liver disease in this setting.

\section{Authors' affiliations}

A Hoi, G O Littlejohn, Department of Rheumatology, Monash Medical Centre, 246 Clayton Road, Clayton Victoria 3168, Australia

Correspondence to: Professor G O Littlejohn geoff.littlejohn@med.monash.edu.au

Accepted 2 September 2002

\section{REFERENCES}

1 Smolen JS, Kalden JR, Scott DL, Rozman B, Kvien TK, Larsen A, et al. Efficacy and safety of leflunomide compared with placebo and sulphasalazine in active rheumatoid arthritis: a double-blind randomised, multicentre trial. Lancet 1999;353:259-66.

2 Strand V, Cohen S, Schiff M, Weaver A, Fleischmann R, Cannon G, et al. Treatment of active rheumatoid arthritis with leflunomide compared with placebo and methotrexate. Arch Intern Med 1999;159:2542-50.

3 Sharp JT, Strand V, Leung H, Hurley F, Loew-Friedrich I. Leflunomide Rheumatoid Arthritis Investigators Group. Treatment with leflunomide slows radiographic progression of rheumatoid arthritis. Arthritis Rheum 2000:43:495-505

4 Emery P, Breedveld FC, Lemmel EM, Kaltwasser JP, Dawes PT, Gomor B et al. A comparison of the efficacy and safety of leflunomide and methotrexate for the treatment of rheumatoid arthritis. Rheumatology (Oxford) 2000:39:655-65.

5 Scott DL, Smolen JS, Kalden JR, Van de Putte LBA, Larsen A, Kvien TK, et al. Treatment of active rheumatoid arthritis with leflunomide: two year follow up of a double blind, placebo controlled trial versus sulfasalazine. Ann Rheum Dis 2001;60:913-23.

6 Cohen S, Cannon GW, Schiff M, Weaver A, Fox R, Olsen N, et al. Two-year, blinded, randomised, controlled trial of treatment of active rheumatoid arthritis with leflunomide compared to methotrexate. Arthritis Rheum 2001;44:1984-92.

7 Weinblatt ME, Kremer JM, Coblyn JS, Maier AL, Helfgott SM, Morrell $M$, et al. Pharmacokinetics, safety, and efficacy of combination treatmen with methotrexate and leflunomide in patients with active rheumatoid arthritis. Arthritis Rheum 1999;42:1322-8.

8 Kremer J, Genovese M, Cannon GW, Caldwell J, Cush J, Weisman M, et al. Combination of leflunomide and methotrexate in patients with active rheumatoid arthritis failing MTX monotherapy: an open-label extension study [abstract]. Arthritis Rheum 44(suppl 9):S549.

9 Kremer JM, Furst DE, Weinblatt ME, Blotner SD. Significant changes in serum AST across hepatic histological biopsy grades: prospective analysis of 3 cohorts receiving methotrexate therapy for rheumatoid arthritis. J Rheumatol 1996:23:459-61.

10 Kremer JM, Alarcon GS, Lightfoot RW, Willkens RF, Furst DE, Willaims J, et al. Methotrexate for rheumatoid arthritis - suggested guidelines for monitoring liver toxicity. Arthritis Rheum 1994;37:316-28.

11 Kremer JM. Not yet time to change the guidelines for monitoring methotrexate liver toxicity: they have served us well. J Rheumatol 2002;29:1590-2. 


\title{
Magnetic resonance imaging of the hand in mixed connective tissue disease
}

\author{
M A Cimmino, A lozzelli, G Garlaschi, E Silvestri, C Montecucco
}

Ann Rheum Dis 2003;62:380-381

M ixed connective tissue disease (MCTD) is a systemic disease identified by Sharp and coworkers in 1972, ${ }^{1}$ which shows some of the clinical and pathological features of other connective tissue diseases such as systemic lupus erythematosus (SLE), systemic sclerosis (SS), and polymyositis. Although it is characterised by high concentrations of anti-UIRNP antibodies, the very definition of MCTD as a distinct entity is still under debate despite the number of immunogenetic, immunological, and clinical studies that have been carried out. ${ }^{2}$

Imaging of the joints in MCTD is based on traditional radiology. Features characteristic of SS (soft tissue atrophy, calcifications, tuftal resorption, distal interphalangeal joint erosions), of rheumatoid arthritis (RA) (juxta-articular osteoporosis, joint space narrowing, marginal erosions), and of SLE (joint deformities without erosions, osteonecrosis) have been described. ${ }^{4}$ Magnetic resonance imaging (MRI) is better than conventional radiology in many instances because of its multiplanar capacity and higher sensitivity. ${ }^{5}$ We describe here the MRI appearance of the hands in two patients with MCTD.

\section{CASE REPORTS}

Two women, aged 32 and 25 years, were diagnosed with MCTD according to the criteria of Alarcon-Segovia and Villareal. ${ }^{6}$ Disease duration was six and 24 months, respectively. Both patients showed arthritis of the wrist and of several metacarpophalangeal (MCP) and interphalangeal joints, as well as dorsal oedema of the hands, Raynaud's phenomenon, and xerophthalmia. Swelling of the parotid gland, myositis, and photosensitivity were present in one patient. MRI was performed using a 0.2 T dedicated MRI system (Artoscan, ESAOTE, Genova, Italy). The technical details of the sequences are given in the legend to fig 1.

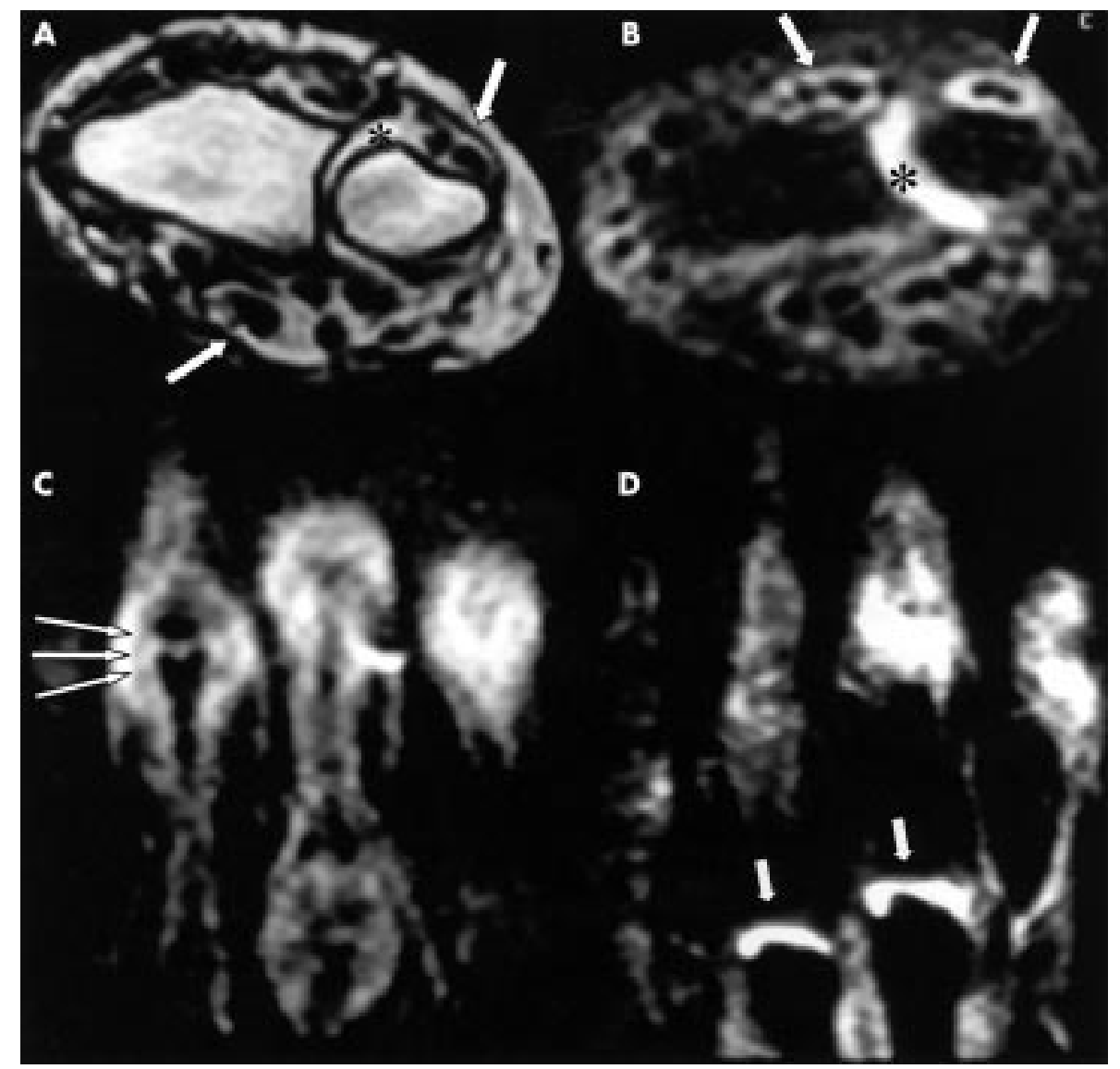

Figure 1 (A) Patient 1: synovitis/effusion around the ulnar styloid (asterisk) and tenosynovitis of the flexor and extensor tendons (arrows) ( $T_{1}$ weighted GE sequence on axial plane; TR/TE/FA/NEX $=400 \mathrm{~ms} / 16 \mathrm{~ms} / 75^{\circ} / 2$ ). (B) Patient 2: intense synovitis of the radioulnar joint (asterisk) and extensor tenosynovitis (arrows) causing thickening of the dorsum of the hand ( $T_{1}$ weighted STIR sequence on axial plane;

TR/TE/FA/NEX=1520 ms/24 ms/90\%/1). (C) Patient 1: synovitis/effusion and pericapsular oedema is seen in the second PIP joint. The distended capsule is indicated by the arrows. (D) Patient 2: intracapsular synovial effusion and/or synovitis of the third and fourth MCP joints (arrows) (both are $\mathrm{T}_{1}$ weighted STIR sequences on coronal planes; TR/TE/FA/NEX=1520 ms $/ 24 \mathrm{~ms} / 90^{\circ} / 1$ ). MRI was performed with a $0.2 \mathrm{~T}$ dedicated system using a wrist coil with field of view of $11 \mathrm{~cm}$. Slice width was $3 \mathrm{~mm}$ with a gap of $0 \mathrm{~mm}$. 
Both patients with MCTD had a positive antinuclear antibody assay (titre $>1 / 2560$ ) and negative anti-dsDNA assay. Anti-RNP antibodies with titre $>200 \mathrm{U} / \mathrm{ml}$ were found by enzyme linked immunosorbent assay (ELISA; ORGentec Diagnostica Kit, Mainz, Germany). Anti-70 kDa, -A, and -C specificity was seen by immunoblotting. Patient 1 also showed high titre anti-SSA(Ro) antibodies against $52 \mathrm{kDa}$ Ro protein. Antibodies to Sm, SSB(La), topisomerase I, and $\mathrm{Ku}$ were absent.

Synovitis/effusion of the wrist, MCP and proximal interphalangeal (PIP) joints without erosions (fig l) were seen in both patients with MCTD. It seemed confined to the intracapsular area in the MCP joints of patient 2 (fig 1D) but was also extracapsular in the PIP joint of patient 1 (fig lC). In addition, tenosynovitis of the extensor and flexor tendons, and oedema of the dorsum of the hand were seen. Bone oedema, which was seen in the capitate of patient 1 (not shown) disappeared after two years' treatment with steroids and azathioprine.

\section{DISCUSSION}

Although a few papers cite MCTD in passing among the inflammatory conditions studied by MRI, ${ }^{78}$ the MRI features of this disease have not been described. The most evident MRI finding in our patients with MCTD was tenosynovitis and arthritis. There were no erosions in our patients, a finding that differs from those of several radiographic studies. ${ }^{4}$ We postulate that this discrepancy may depend on the relatively early stage of MCTD in our patients. Bone oedema, an inflammatory lesion of the subchondral bone which can precede erosions in RA, was seen but reverted to normal after successful treatment. In MCTD, both intracapsular and extracapsular inflammation was observed. Oedema and inflammation of the pericapsular area is a feature which, according to a recent study, ${ }^{9}$ can be seen in seronegative spondyloarthropathies. On the contrary, it is rare in RA, a condition in which inflammation is usually confined to the articular capsule.

In conclusion, the MRI features of the hand in these two patients were not typical for MCTD alone, for they are also present in other connective tissue diseases considered in the differential diagnosis. If these findings were confirmed on a larger number of cases, however, a characteristic MRI pattern of MCTD might be identified that could prove helpful in the differential diagnosis of early patients with connective tissue diseases affecting the hand.

Authors' affiliations

M A Cimmino, Clinica Reumatologica, DI.M.I., Università di Genova, Genova, Italy

A lozzelli, G Garlaschi, E Silvestri, Sezione di Diagnostica per

Immagini, DI.ME.S., Università di Genova, Genova, Italy

C Montecucco, Clinica Reumatologica, IRCCS S.Matteo, Università di Pavia, Italy

Correspondence to: Dr M A Cimmino, Clinica Reumatologica, Dipartimento di Medicina Interna e Specialità Mediche, Viale Benedetto XV, 6, 16132 Genova, Italy; cimmino@unige.it

Accepted 8 August 2002

\section{REFERENCES}

1 Sharp GC, Irvin WS, Tan EM, Gould RG, Holman HR. Mixed connective tissue disease - an apparently distinct rheumatic disease syndrome associated with a specific antibody to an extractable nuclear antigen (ENA). Am J Med 1972:52:148-59.

2 Maddison PJ. Overlap syndromes and mixed connective tissue disease. Curr Opin Rheumatol 1991;3:995-1000.

3 Smolen JS, Steiner G. Mixed connective tissue disease: to be or not to be? Arthritis Rheum 1998:41:768-77.

4 Resnick D. Mixed connective tissue disease and collagen vascular overlap syndromes. In: Resnick D, ed. Diagnosis of bone and joint disorders. Philadelphia: Saunders, 1995: 1242-51.

5 Cimmino MA, Bountis C, Silvestri E, Garlaschi G, Accardo S. An appraisal of magnetic resonance imaging of the wrist in rheumatoid arthritis. Semin Arthritis Rheum 2000:30:180-95.

6 Alarcon-Segovia D, Villareal M. Classification and diagnostc criteria for mixed connective tissue disease. In Kasukawa R, Sharp GC, eds. Mixed connective tissue disease and antinuclear antibodies. Amsterdam: Elsevier, 1987:33-40.

7 Savnik A, Halmskov H, Graff LB, Thomsen HS, Nielsen H, Boesen J, et al. The relationship between MRI-determined enhancement and clinical parameters [abstract]. Ann Rheum Dis 2000;59(suppl I): 109.

8 Treadwell EL. Synovial cysts and ganglia: the value of magnetic resonance imaging. Semin Arthritis Rheum 1994;24:61-70.

9 McGonagle D, Gibbon W, Emery P. Classification of inflammatory arthritis by enthesitis. Lancet 1998;352:1137-40. 